Marquette University

e-Publications@Marquette

English Faculty Research and Publications

English, Department of

$3-1-1950$

On Chaucer's Source for "Arveragus" in the Franklin's Tale

Jerome W. Archer

Marquette University

Published version. PMLA, Vol. 65, No. 2 (March 1950): 318-322. DOI. (C) 1950 Modern Language Association. Used with permission. 
der mhd. Dichtung (Bern, 1936), 114, interessante Stellen gesammelt, in denen Gott unter dem Bilde des Künstlers gesehen wird: Gott ist ein wercwîser meister; Gott selbst versteht zu dichten, der tihte menschen leben; got die nature hât geticht usw. Im Variloquus (1478) findet sich die merkwürdige Verdeutschung poeta = naturlicher maister, womit angespielt ist auf die Vulgata-Stelle Hebr. 11: 10 "expectabat civitatem, cuius artifex et conditor est deus," was die Druckbibeln vor Luther wiedergeben durch: "Wann er harret der statt, der gott was ein meister und ein Macher." Luther schreibt: "Denn er wartet auff eine stad, welcher Bawmeister vnd Schepffer Gott ist."

Meister und Schöpfer, Poeta, das ruft Erinnerungen an Platos Timaeus wach, wo der Schöpfer als Demiurg, als Baumeister des Kosmos angesprochen wird. Für den Rest geht der Germanist beim Romanisten und Anglisten in die Schule und läßt sich von E. R. Curtius belehren, daß grade Timaeus der einzige dem Mittelalter bekannte Plato-Text war, daß für Plato Poiesis alles Erzeugen von Gegenständen ist, daß über Origines dem Christentum das Bild zukommt vom göttlichen Demiurgen, dessen Schöpfung ein vollkommen schönes Kunstwerk ist. ${ }^{9}$ Glunz überschreibt das zweite Kapitel seiner Literatur- Ästhetik des europäischen Mittelalters (Köln, 1937) gradezu "Deus Poeta" und den Abschnitt S. 175-185 "Gott als Künstler und Dichter."

Auch wer sich den scharfen kritischen Gedankengängen des Aufsatzes von Curtius nicht verschließt, wird doch nicht umhin können, die Glunzsche Gleichung Deus est Verbum wiederzufinden im schon früher angeführten Anfang des zweiten Buchs von Otfrids Evangeliengedicht: "In principio erat verbum. Et verbum erat apud deum. Et deus erat verbum." Worauf dann jene obenzitierten Verse folgen, deren Stimmungsverwandtschaft und inhaltliche Identität mit der Wessobrunner Kosmogonie längst hätte bemerkt werden sollen. Hier ist die Schöpfung erzählt unter der Utberschrift Deus erat verbum; dort folgt sie einem Titel De poeta.

The Johns Hopkins University

ARNO SCHIROKAUER

\section{ON CHAUCER'S SOURCE FOR “ARVERAGUS” IN THE FRANKLIN'S TALE}

HALF a century ago, in his article, "Chaucer's Franklin's Tale," W. H. Schofield pointed out that Geoffrey of Monmouth in his Historia Regum Britannice had something to say about a British king Arviragus and his wife Genuissa, and

${ }^{9}$ Bisher zu finden in den drei Aufsätzen "Zur Literarästhetik des Mittelalters," Zeitschrift für Romanische Philologie, LVIII (1938), besonders S. 18 ff. Jetzt aber weiter ausgeführt und gegründeter in Europäische Literatur und Lateinisches Mittelalter (Bern, 1948) im Exkurs über Macrobius (S. 442 ff.), wo es z.B. heißt: "Es besteht eine grosse Ähnlichkeit zwischen dem divinum opus mundi und dem poeticum opus; zwischen dem deus opifex und dem poeta." Und wenig später: "Entscheidend ist dabei die Vorstellung von einer Analogie des dichterischen Schaffens mit dem Prozeß der Weltentstehung." Vgl. dazu auch Exkurs xxi, 529 f., mit dem Titel "Gott als Bildner." 
about a British king Aurelius whose magician moved huge stones. ${ }^{1}$ But this material, Schofield concluded, is too sketchy and bare to have proved attractive to Chaucer as source material for his tale; it is, rather, analogous. Therefore, something else must be the source, and Schofield argued for a Breton lay. In this, he was opposed by several, including J. S. P. Tatlock and Germaine Dempster, authors of the article on the Franklin's Tale in the recent Sources and Analogues of Chaucer's "Canterbury Tales."2

I wish to suggest that complexity still exists in the relationship of Geoffrey of Monmouth's Historia to the Franklin's Tale, and that we should regard as doubtful the view accepted in the Sources and Analogues article that Greoffrey is the direct source for Chaucer's name for Arveragus who had a wife named Dorigen (=Geoffrey's Genuissa?), and for an Aurelius who had a magician move huge stones. This view is based, so far as I can see, upon Tatlock's argument in his The Scene of the Franklin's Tale Visited. ${ }^{3}$ The argument goes as follows: Schofield's theory of Chaucer's source as a Breton lay which, or the substance of which, Geoffrey of Monmouth may have known, or from which he received his names, "is not the most natural explanation of the relation"4 of Geoffrey's matter to Chaucer's, for

Needing ancient British names, what more natural [i.e., for Chaucer] than to resort to the Historia Regum Britanniae? And an almost conclusive argument against Dr. Schofield's interpretation is that in not one of the Breton lays extant in French or English is there a single character whose name has a Latin form. . . . Did he [Chaucer] not rather cast about for ancient names to carry out the ancient air of his poem and extract them from Geoffrey?5

But was it "natural" for Chaucer in this tale exalting the virtue of keeping one's word, of holding to the "trouthe," to take the names of Arveragus and Aurelius from Geoffrey of Monmouth when there is no direct reference in Geoffrey to anything similar to the essential theme of Chaucer's tale, or, except for the rocks episode, anything similar to the main narrative of the tale? If Chaucer were merely looking around for British names, he seems to have had no trouble in finding one (or what he apparently regarded as one) in Dorigen, and that name is not found in Geoffrey's Historia. And as for the absence of names in Latin forms in extant Breton lays in French or English, surely such lays are too few to produce an "almost conclusive argument" in this respect against Schofield. ${ }^{7}$

1 PMLA, xvi (1901), [405-449], 409-423.

2 Edd. W. F. Bryan and G. Dempster (Chicago, 1941), p. 383, q.v. for bibliography on this subject.

3 (Chaucer Society, 1914), pp. 62-74.

${ }^{4}$ Ibid., p. 68.

${ }^{5}$ Ibid.

${ }^{6}$ Schofield, p. 437, regarded this as the great moral of the tale; F. N. Robinson, ed. The Complete Works of Geoffrey Chaucer (Boston, 1933), p. 831, says that it is the "first moral" and that the "second virtue... is gentilesse."

${ }^{7}$ Outside the Breton lay, in Geoffrey's Historia e.g., we find both British and Latin forms for names of British characters; and, in Layamon's Brut (in Madden's ed.), for Arviragus we have the forms (in the earlier text): Aruiragus, 9254, 9367, 9433; Aruiragun, 9189; Aruiragune, 9187, 9499. 
Why would Chaucer go to the character of Arviragus for a name at all, unless he found Arviragus in a story with a theme similar to that of his tale? Of the British ruler Arviragus, and his wife Genuissa, Geoffrey's Historia (bk. Iv, chs. 15-16) tells us no more than that their marriage was a great event, that Arviragus after the marriage was kindled with such fervor for his wife that he preferred her to all things, that he persuaded his father-in-law to build a city in honor of the marriage, and that later the wife was a successful mediator for peace between her husband's armies and those of the Romans. Nothing here shows us that the marriage is a happy one, ${ }^{8}$ and, as Schofield had observed, ${ }^{9}$ nothing here expresses or stresses the virtue of keeping one's word.

But evidence exists, I believe, to show that Arviragus and his wife were, before Chaucer, associated with the subject of a happy marriage and loyalty to a pledge. It is in Layamon's Brut, lines $9808-55,{ }^{10}$ in material neither in Geoffrey of Monmouth nor, as Madden observed, ${ }^{11}$ in Wace.

Where in Geoffrey we have merely the statement that Queen Genuissa mediated as peacemaker between her British husband and the Romans, to whom he no longer intended to be vassal or to pay tribute, in Layamon's presentation we have, as first to be noted, Genuissa's love for Arviragus: she "cleopede to hire lauerde, be leof hire wes on heorte" (11. 9812-13). Such affection of wife for husband is found in Chaucer's tale, but not in Geoffrey's Historia. ${ }^{12}$ Although there is no explicit statement in Layamon that Arviragus loves his wife, whereas there is in Geoffrey, in Layamon the success of--what we shall look at in a momentthe wife's plea to her husband might imply his love for her. ${ }^{13}$ At any rate, we have in Geoffrey of Monmouth an Arviragus who loved his wife, and in Layamon a wife who loved her husband Arviragus.

Of greater importance in this passage in Layamon, however, is something that we have not at all in Geoffrey: the long plea, of Genuissa to her beloved husband, based upon the sacredness, virtue, and kingliness of living up to one's plighted word: $:^{14}$

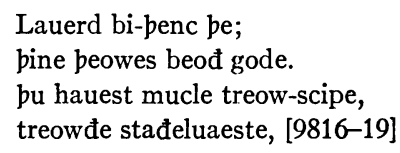

${ }^{8}$ Pio Rajna, himself an opponent of Schofield's lay theory, pointed out ("Le origini della novella narrata dal 'Frankeleyn'...," Romania, xxxII [1903], 207) that Geoffrey's "tantarum ... nuptiarum" (Historia, bk. Iv, ch. 15) did not justify the translation (of Giles, which Schofield used), "of so great and happy a marrriage," and that Geoffrey makes no mention of any affection of the wife for her husband Arviragus.

${ }^{9}$ Op. cit., p. 437.

${ }^{10}$ Frederick Madden ed. (London, 1847), I, 418-420, in the earlier version; the later version has essentially the same matter.

${ }^{11}$ IIr, 340. See Wace's Brut, 5133-54, ed. Ivor Arnold (Paris [SATF], 1938), vol. I (525477 in the Le Roux de Lincy ed., Rouen, 1836-38, vol. I, which Madden used).

${ }^{12}$ See above, note 8.

${ }^{13}$ See also $9856 \mathrm{ff}$. in Layamon.

${ }^{14}$ For Arviragus' promise, see, besides the passage summarized here, 9498-9535 in Layamon; cp. Geoffrey's Historia, bk. Iv, ch. 14 . 
qualities which, she says, are proper for every king, rich man and poor man. "Bi-benc bu a bine quides" (9824 ff.), she pleads, which you spoke to my father, Claudius, who gave me as wife to you, who are so dear to me as my lord;

$\&$ bi-penc be of ban fore,

hu bu mine fader swore [9846-47]

to pay tribute to Rome. Therefore-she ends her exhortation-

... pu most holdē

pat bu aer bihaehtest. [9854-55]

This plea, apparently overlooked by Schofield, ${ }^{15}$ is surely a significant addition to what Geoffrey (and Wace) had to say. ${ }^{16}$ It shows that an Arviragus and his wife were associated with a story dealing with the importance of the plighted word, and that consequently Chaucer could have and probably must have heard or read some account which carried on this association of an Arviragus and his wife with such a virtue. This explanation for the source of Chaucer's name for Arveragus is at least as natural as that which calls for Chaucer going to Geoffrey's Historia just to get British names.

The shifting in Chaucer's tale of the plea to live up to the truth from the wife to the husband may be accounted for either (1) by whatever were the intermediate sources or source between the original and Chaucer, or (2) by the possibility that Chaucer, taking the story from Boccaccio, took the name of Arveragus and possibly that of Dorigen (=Genuissa?) from some chronicle or other source, similar to Layamon's Brut, in which the names were associated with truth as in Layamon, and then used them to suit his story. ${ }^{17}$

When one begins to doubt that Geoffrey's Historia is the direct source for Chaucer's Arveragus, he begins to wonder, of course, about the relation of Chaucer's Aurelius-who hires a magician who, by "swiche illusiouns and swiche meschaunces As hethen folk useden in thilke dayes,"18 causes rocks to disappear,

${ }^{15}$ Op. cit., p. 413, n. 1: "In the life of Arviragus the English historian [Layamon], as usual, greatly expands Wace, his original ..., but here without adding anything really significant."

${ }^{16}$ The possibility that Layamon concocted this material seems unlikely, for Chaucer's association of Arveragus and his wife with a plea for the keeping of one's pledge seems to have not a coincidental but an analogous relationship to Layamon's matter, pointing to some common source or tradition. If he did not concoct it, this material is further evidence that Layamon added a good deal from his own reading or knowledge to what he found in Wace, and in Wace's source, Geoffrey. Although some have regarded Layamon's additions as largely creations of his own, the latest editor of any considerable portion of the Brut, Joseph Hall (Selections [Oxford, 1924], p. vi), thought it "highly probable that ... Layamon ... had gathered much legendary lore in his wanderings and had wrought it into the texture of his poem." Cp. substantially the same view of Madden ( $\mathrm{I}, \mathrm{xvi}$ ), and his further view (and of course that of others), which the evidence of this paper tends to support, that Geoffrey "was not a mere inventor."

${ }^{17}$ Cp. what J. Burke Severs- "Chaucer's Originality in the 'Nun's Priest's Tale'," $S P$, XLIII (1946), 28-29-shows may have happened in Chaucer's handling of his source material in the $N P T$.

${ }^{18}$ FrklT, 1292-93 (Robinson ed.). Italics mine. 
or to seem to disappear, from the sea-to Geoffrey of Monmouth's Aurelius, whose magician, Merlin, moves huge stones from one land to another. Now although Chaucer, so far as we know, is in none of his works (unless in the Franklin's Tale) indebted to Geoffrey of Monmouth, it seems probable that, wide reader as he was, he knew the easily available Historia of "Englyssh Gaufride" (House of Fame, 1. 1470) fairly well. If he knew it at all well,,$^{19}$ he must have known that Geoffrey of Monmouth's Aurelius (Ambrosius), brother of Uther Pendragon, is a famous Christian hero-king to whose exploits against the pagan Hengist and his Saxons Geoffrey devotes all of the first sixteen chapters (about fifteen pages in print) of Bk. VIII of the Historia. ${ }^{20}$ One doubts that for a work set, as the Franklin's Tale is, among pagans, ${ }^{21}$ Chaucer would have taken Aurelius, or his name, from the character of the Christian leader in the Historia.

Whatever Chaucer's source for Aurelius and the disappearance of the rocks, in both Chaucer and Layamon an Arviragus and his wife are associated with the problem of living up to a pledge. Such evidence, though not establishing nor even, in my opinion, suggesting Layamon as a source for Chaucer for the name of an Arveragus who had a wife (Dorigen = Genuissa?), seems to exclude Geoffrey of Monmouth as a direct source for this matter, and to lend support to the theory that the tale has some source besides Boccaccio (and others)-whether a Breton lay, or French tale, or whatever, it is not within my province to suggest.

\section{Marquette UnIVERsity}

JEROME W. ARChER

Milwaukee 3, Wis.

${ }^{19}$ That he knew the Historia well is at least as likely as F. Lot's view (in a review of Schofield's article, in Moyen Age, vr, 2nd ser. [1902], 111) that Chaucer's knowledge of it was so superficial that he had a confused recollection of Arviragus. On the availability of the Historia, cf. Acton Griscom-ed. Historia (London, 1929), pp. 6-19-who observes that there are at least 190 MSS surviving from the 12 th to the 15 th centuries.

${ }^{20}$ The Aurelius story in Wace (8037 ff. in Arnold's ed.) and in Layamon (17174 ff.) is essentially the same as that in Geoffrey.

${ }^{21}$ Besides the tale, see Tatlock, The Scene ..., p. 20: "Chaucer took much pains to put the story back in Roman times...."

\section{THE RICHELIEU-CORNEILLE RAPPORT}

\section{II}

Since Sister Amelia quotes me in her article $^{1}$ and gives me, to use Richelieu's words, a mixture of "applaudissement et blasme," I must reply to her observations.

In order to support the hypothesis that Richelieu condemned le Cid, she summarizes familiar statements and arguments and adds two of her own, one drawn from Richelieu's alleged piety as a Cardinal, the other from the appointment by the Academy of Desmaretz as one of its judges.

${ }^{1}$ PMLA, LXIV (Sept. 1949), 724-745. 